\title{
The Assessment of Microbiological Indicators in the Freshwaters of Drini River and Lezha Lagoons
}

\author{
Anilda Kokali*1 ${ }^{1}$, Sulejman Sulçe ${ }^{2}$ \\ ${ }^{1}$ Institute of Public Health, Department of Health and Environment, Tirana, Albania \\ ${ }^{2}$ Agricultural University of Tirana, Kamëz, Tirana, Albania
}

\begin{abstract}
In this study we investigated the level of pollution in surface water and sanitation in the sediments on the Drin River in Kune and Vain, through investigation of seasonal variations, the group of bacteria as indicators of microbiological contamination. These parameters include: Total Coliform (TC), Fecal Coliform (FC) Fecal Streptococci (FS) in the surface water and sediments. The samples are taken during 4 seasons of 2012-2013. The samples of water and sediments for microbiological analysis are collected at fifteen monitoring points (5 sampling points in the Drini River along its length, from the bridge Zogaj - Balldre up in the Industrial area, while in Kune-Vain lagoons are defined and taken 4 points sampling on each lagoon. Last 2 sampling points belong to the estuary of the Drin River in the Adriatic Sea). The classification is made and comparisons with EC Directives 2000/60; WHO, USEPA, NIVA. According to the analytical evaluation of samples for microbiological indicators it was observed that the values of these indicators in the samples of sediments have resulted higher than in samples of water. The highest values were found in the sampling stations on the Drini River, followed by the sampling stations at the mouth of the Drini River. Average lower values of (TC), (FC) and (FS) in water, are found in autumn and winter, while the average values are found higher in the spring and summer. Average lower values of (TC), (FC) and (FS) in sediments are found in July '12 while average values higher are found in November '13.
\end{abstract}

Keywords: microbiological indicators, Kune Vain, Drini River.

\section{Introduction}

The contamination of aquatic ecosystems is a threat to the ecosystem itself and for the health of all living things, including humans. Water bodies, in developing countries suffer from the deterioration of water quality through pollution generated by a misuse of these natural resources, where environmental management practices can not ensure compliance with the economic development (Agusto \& Bamigbola, 2007). Water quality through evaluation of physic-chemical, microbiological, toxic to water bodies; often have been the subject of research by many researchers in the field of environmental health (Servais, 2005; Dere et al., 2006; Kirschner.,et al. 2009; Purnell 2011 etc.,). The Reference and the Water Framework Directive 2000/60/EC, which sets out to member states of the European Union, achieving good status quantity and quality of all whole aquatic (including marine waters up to $0.5 \mathrm{~km}$ kilometers from the coast) by 2015 (WFD, 2000).

Increasing quantities of discharged and untreated wastewater, in areas of urban and rural areas due to increased population, increased activity anthropogenic the activities of industry, farming, agricultural production, has increased pressure on these water bodies. These pollutants are transported through precipitation in heavy rain, flooding, etc., interest represents the distribution of pollutants, some of them melt and undergo displacement due to water currents others are absorbed by solid particles in suspension and sediments and others can enter in different biochemical cycles. So, sediments and pollutants are in the continuous aqueous phase and the living organisms that live in them, and then turn themselves in sediment or water pollution source, depending on environmental conditions. For this, it is understood that the quality of water in the course is clearly a reflection of the watershed (Bellinger \& Sigee, 2010; Miho, 2011). As a result, the pollution of water mainly by emissions from urban wastewater as a result of agricultural activity (cultivation of land near rivers, drainage of agricultural land) makes possible the emergence of the phenomenon of eutrophication in these water bodies.

Area under study includes a portion of the Drini river, where the river crosses the town of Lezha and flows into the Adriatic Sea, south of Shengjin between area marsh Kune Vain which is an area of wet complex which includes not only terrestrial habitats swamps and lagoons that surround, but also territories from downstream of the river and its delta. Marsh area of Kune Vain is first protected area in Albania and is declared as hunting reserves and then - Managed Natural Reserve, besides Island Kune belonging category, Strict Nature Reserve. These lagoons are supplied with water as groundwater, surface and them. Drini River, the Adriatic Sea and communication channels with the other lagoon water are affecting the surface water ecosystems Kune Vain, in terms of flow of pollutants. Supplying contaminated water lagoons for several reasons, among which are: lack of urban wastewater treatment, industrial water, and wastewater generated from agricultural activities, urban waste. The sewage and industrial are originating from the town of Shengjin, Lezha city, lagoons and surrounding villages. In the lagoon Vain pumping station of Tales, which flows to its south, collects mostly water farming, but when there is an overload collects and waste water and discharge into the lagoon Vain, near Matkeqe's canal, which is currently closed. Drini River, bringing waste from other areas, before described the city, passing in some rural areas, where the host serves as collector of waste water discharges untreated of point source and diffuses, thus deteriorating the quality of its waters. Heavy flooding characteristic of the area, rinse the 


\section{International Journal of Science and Research (IJSR) \\ ISSN (Online): 2319-7064}

Index Copernicus Value (2013): 6.14 | Impact Factor (2014): 5.611

surface of agricultural land along the river, the river flow into the lagoon, taking with them various pollutants, organic matter and nutrients.

Being under this constant pressure, sanitary quality of surface waters in the Drini River has deteriorated, but on the other hand has affected the sanitary quality of surface water lagoon.

\section{Sampling and Analytical Methods}

The microbiological qualities of water are conditioned by wastewater discharge of untreated urban and rural areas in the marine environment host, in this study the surface water of the Drini River in the lagoon waters. The area under study is an area that as a result of events weather flooded often, large quantities of water serve as carriers of microbiological contaminants of physic chemical, affecting the quality of these waters host (in case of floods, large quantities of water pumped directly into the lagoon Vain).

The selection and sampling is carried out based on the unified guidelines of the Institute of the Environment (Reference: Selection and Development of methods of sampling and analysis of the elements of environmental contaminants in water monitoring, referring to methods of international standards for obtaining Water samples).

It made design and determination of the sampling points on the ground, the location coordinates (15 points). 5 are selected sampling points along the Drini River Bridge Balldre-Zogaj (point1) until the industrial area (point 5), while in the lagoons of Kune Vain are selected from 4 sampling points. At the outfall of the Drini River, the Adriatic Sea are selected 2 samples taken points (point 14 point 15, respectively D1 - D2) (Fig 1, Fig 2).

The water samples are taken in 4 seasons during the years 2012-2013, while the sediment samples are taken once a year. The water samples are taken in $500 \mathrm{ml}$ sterile bottles at a depth of $0.30 \mathrm{~m}$ and distance from shore more than 30 meters. Sediment samples are taken at the same coordinates that are taken and samples of water, at a depth of $0-10 \mathrm{~cm}$ in sterile polyethylene bags. The samples are sent to the laboratories of IPH, within 12 hours of being transported in ice box temperature $4^{0} \mathrm{C} \pm 2{ }^{\circ} \mathrm{C}$.

Analytical procedure: The microbiological analysis of the market is made using the technique of Membrane filtrate (MF) according to the ISO 9308 - 1, 2, 3:1998, ISO 7899 - 1, $2: 1998$; through the filtering method with the vacuum pump, which was screened through a sterile funnel of $100 \mathrm{ml}$ quantity of water for each analysis. The membrane filters were used with a diameter of $47-50 \mathrm{~mm}$ with a pore size of $0.45 \mu \mathrm{m}$, in which the bacteria remain present in the water sample. Paper filter was later transferred to the culture medium ready dehydrated, selective mediums which were then incubated. All samples of water, are analyzed for three microbiological indicators, previously are filtered and diluted.
For the determination of the Total Coliform and Fecal Coliform is used medium ECD (MUG, 4-methylumbelliferyl$\beta$-D-glucuronide) and incubation is conducted in thermostat, temperature to $37^{\circ} \mathrm{C}$ (TC) for $21 \pm 3$ hours and $44^{\circ} \pm 0.5^{\circ}$ (FC) for 36 hours minimum and 72 hours maximum. The dishes are examined under ultraviolet light with wavelengths of $366 \mathrm{~nm}$ in the dark.

For definition of fecal streptococci (FS), are used medium Slanetz \& Bartley (TTC) and incubation is done in the thermostat at a temperature of $44^{0} \mathrm{C} \pm 0.5^{\circ} \mathrm{C}$ for $48 \pm 3$ hours.

The results are reported as CFU/100 $\mathrm{ml}$ of water tested. It was controlled authenticity of microbiological analysis, using as a blank sample without the presence of the medium. To realize the quality control of microbiological analysis was used Indole reagent. Membrane filter with Total coliform and Fecal coliform was transferred to agar trypton, warmed to 19 20 hours in $44^{0} \mathrm{C} \pm 0.5^{\circ} \mathrm{C}$; then filter membrane reagent was added Indol, red appearance confirmed coliform colonies. For confirmation of fecal streptococcus presence, filter membrane of fecal streptococcus, was transferred to the bile esculin azide agar, incubated in $44^{0} \pm 0.5^{\circ} \mathrm{C}$ for 1 hour. The appearance of dark brown to the black colonies confirms the presence of the Streptococci.

Statistical analyzes were performed using the statistic software SPSS 16. In each sampling point, three samples were taken in order to allow statistical analysis attempting a normal value (in the table is expressed averaging the value for each parameter.

\section{Figures and Tables}

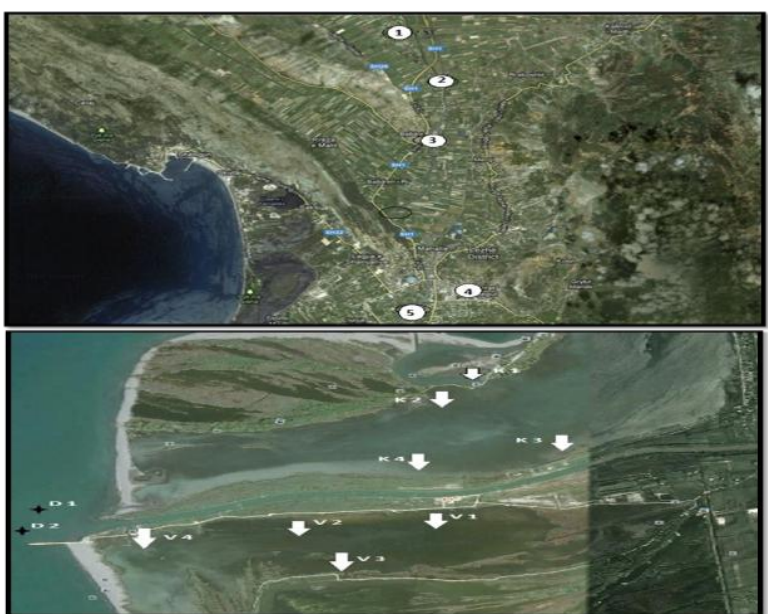

Figure 1; Figure 2. Sampling sites along the Drini River and Kune Vain Lagoons

Table 1: Minimum values, Maximum, Mean and Standard Deviation in samples of water, during years $2012-2013$.

\section{Volume 5 Issue 1 January 2016}




\section{International Journal of Science and Research (IJSR) \\ ISSN (Online): 2319-7064}

Index Copernicus Value (2013): 6.14 | Impact Factor (2014): 5.611

\begin{tabular}{|c|c|c|c|c|}
\hline WATER & \multicolumn{4}{|c|}{ Total coliforms (TC) } \\
\hline Period & Min & $\operatorname{Max}$ & Mean & Mean $\pm S D$ \\
\hline January 2012 & 15 & 3560 & 579 & $579 \pm 1078$ \\
\hline March 2012 & 50 & 12600 & 1748 & $1748 \pm 3888$ \\
\hline July 2012 & 96 & 19200 & 2958 & $2958 \pm 6453$ \\
\hline November 2012 & 26 & 6250 & 1056 & $1056 \pm 1941$ \\
\hline January 2013 & 18 & 6150 & 1217 & $1217 \pm 2198$ \\
\hline March 2013 & 52 & 24800 & 5905 & $5905 \pm 8562$ \\
\hline July 2013 & 38 & 17640 & 5697 & $5697 \pm 7549$ \\
\hline November 2013 & 26 & 10756 & 1630 & $1630 \pm 3546$ \\
\hline WATER & \multicolumn{4}{|c|}{ Escherichia coli $(E C)$} \\
\hline Period & Min & $\operatorname{Max}$ & Mean & Mean $\pm S D$ \\
\hline January 2012 & 8 & 1720 & 302 & $302 \pm 555$ \\
\hline March 2012 & 12 & 7000 & 941 & $941 \pm 2128$ \\
\hline July 2012 & 13 & 18300 & 2557 & $2557 \pm 6139$ \\
\hline November 2012 & 7 & 3300 & 556 & $556 \pm 1042$ \\
\hline January 2013 & 8 & 5150 & 951 & $951 \pm 1844$ \\
\hline March 2013 & 18 & 18900 & 4487 & $4487 \pm 6617$ \\
\hline July 2013 & 3 & 16380 & 4685 & $4685 \pm 6846$ \\
\hline November 2013 & 3 & 9200 & 1331 & $1331 \pm 3179$ \\
\hline WATER & \multicolumn{4}{|c|}{ Fecal streptococci $(F S)$} \\
\hline Period & Min & $\operatorname{Max}$ & Mean & Mean $\pm S D$ \\
\hline January 2012 & 0 & 910 & 141 & $141 \pm 277$ \\
\hline March 2012 & 0 & 5040 & 611 & $611 \pm 1561$ \\
\hline July 2012 & 0 & 9040 & 1127 & $1127 \pm 2831$ \\
\hline November 2012 & 0 & 2510 & 338 & $338 \pm 770$ \\
\hline January 2013 & 0 & 1540 & 223 & $223 \pm 490$ \\
\hline March 2013 & 4 & 22680 & 4453 & $4453 \pm 6991$ \\
\hline July 2013 & 0 & 15120 & 4165 & $4165 \pm 6192$ \\
\hline November 2013 & 0 & 1400 & 210 & $210 \pm 453$ \\
\hline
\end{tabular}
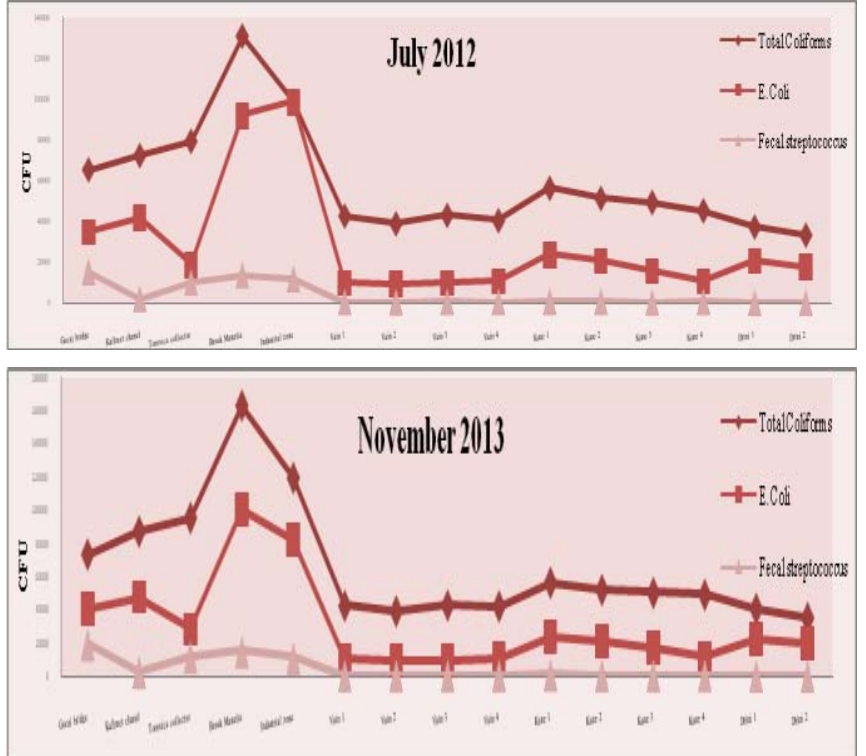

Graphics 2: Seasonal variation of microbial indicators in sediments, during years 2012-2013.
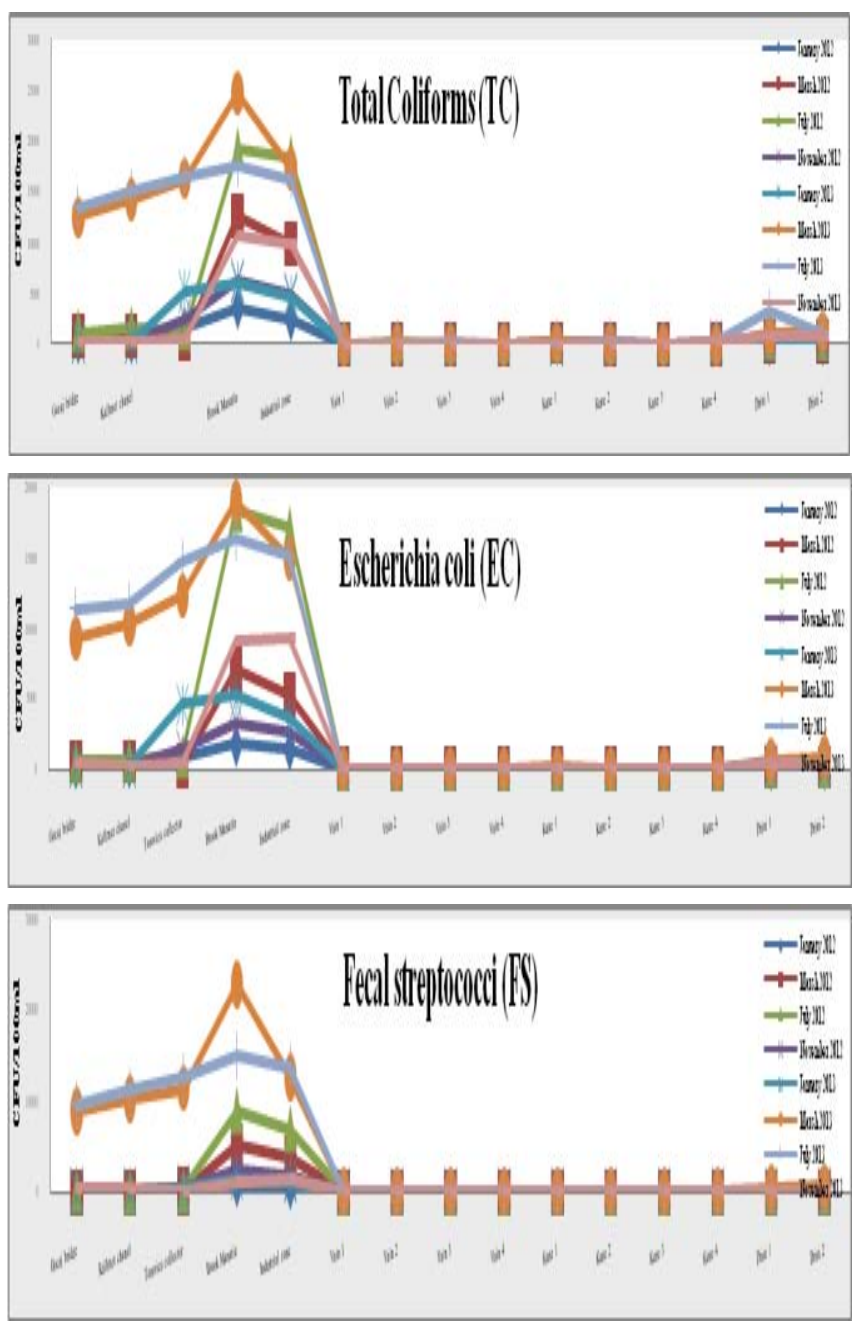

Graphics 1: Seasonal variation of microbial indicators in water, during years 2012-2013.
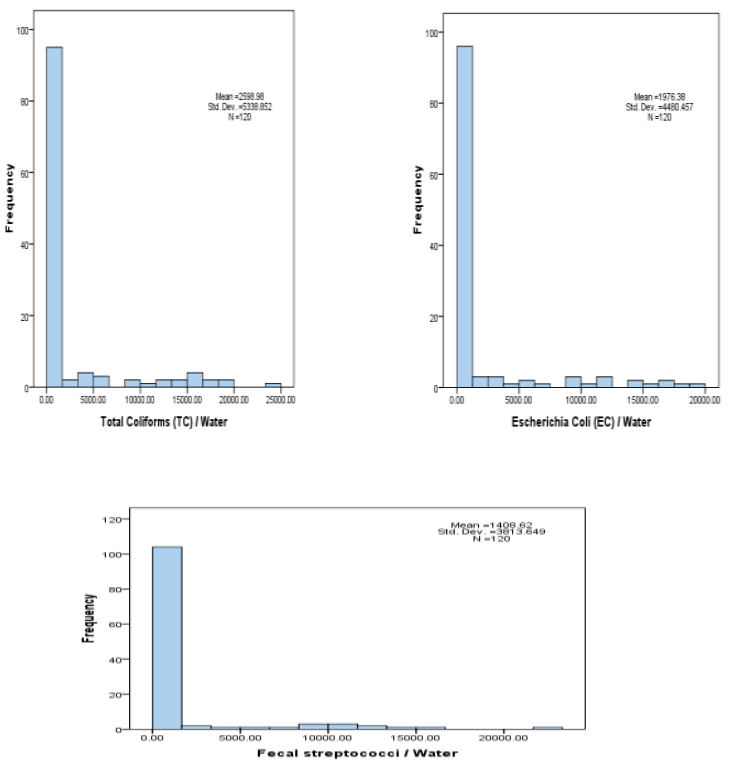

Figure 3: Test of Normality, histograms, for bacteriological water indicators, during years 2012-2013. 


\section{International Journal of Science and Research (IJSR) \\ ISSN (Online): 2319-7064}

Index Copernicus Value (2013): 6.14 | Impact Factor (2014): 5.611

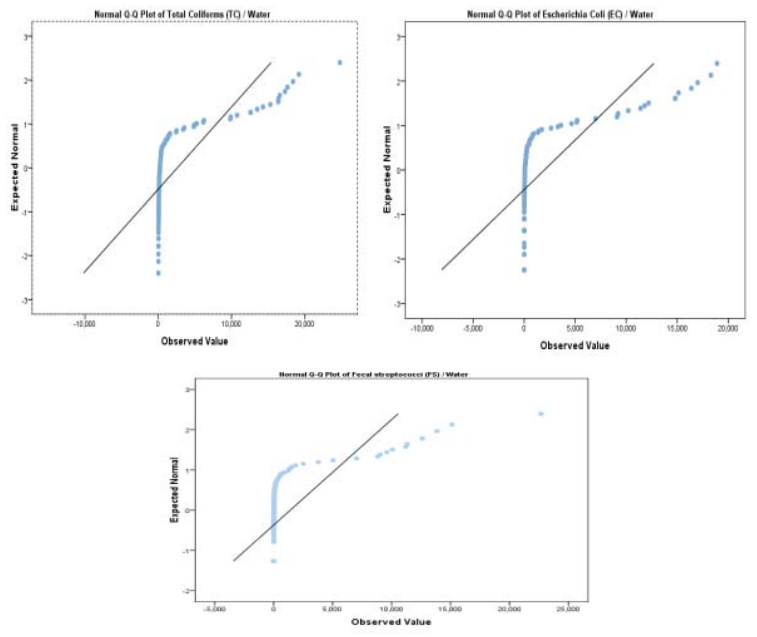

Figure 3: Test of Normality, graphs, for bacteriological water indicators, during years 2012-2013.
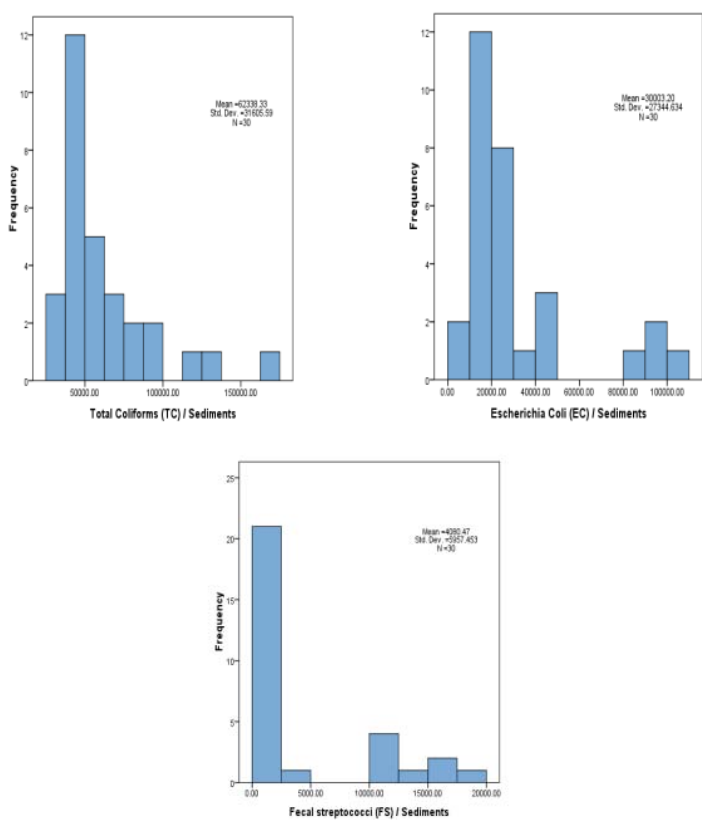

Figure 4: Test of Normality, histograms, for bacteriological sediments indicators, during years 2012-2013.
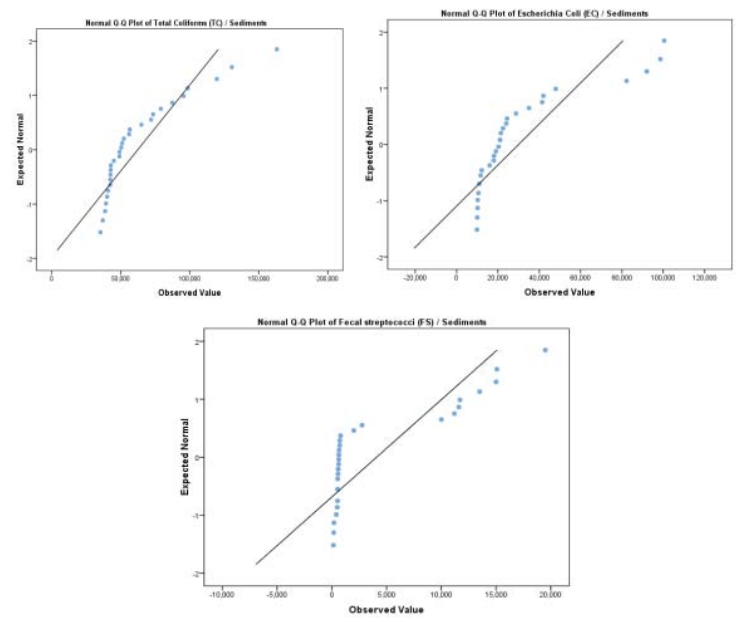

Figure 4: Test of Normality, graphs, for bacteriological sediments indicators, during years 2012-2013.
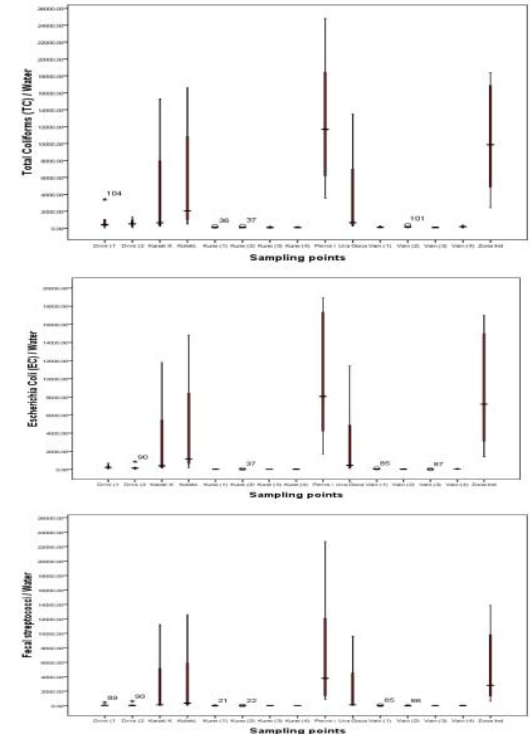

Figure 5: Box plots, graphical presentation of the distribution of microbial indicators in water, during years $2012-2013$
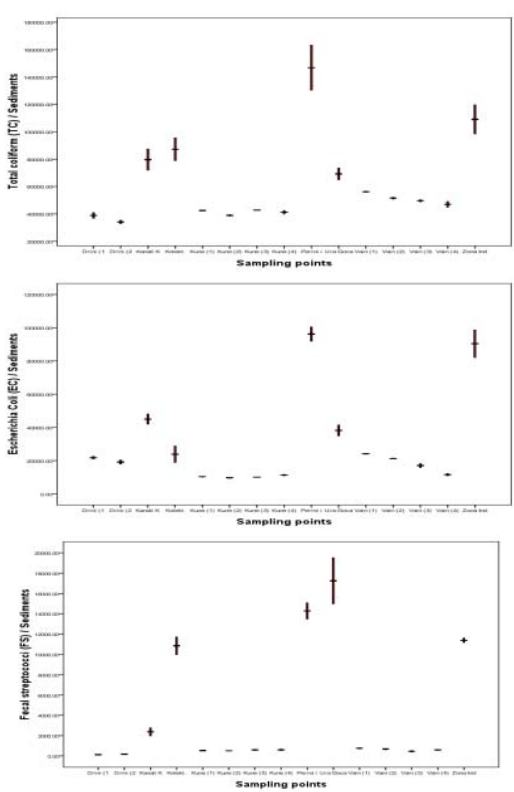

Figure 6: Box plots, graphical presentation of the distribution of microbial indicators in water, during years $2012-2013$

\begin{tabular}{||c|c|c|c||}
\hline Water & TC & EC & FS \\
\hdashline TC & 1 & & \\
\hdashline EC & 0.92 & 1 & \\
\hdashline FS & 0.83 & 0.91 & 1 \\
\hline
\end{tabular}

(Tab.4): Spearmen Correlation, between microbial indicators in water (during years 2012 -2013).

\begin{tabular}{|c|c|c|c|}
\hline $\begin{array}{c}\text { Sediment } \\
s\end{array}$ & $\mathrm{TC}$ & $\mathrm{EC}$ & $\mathrm{FS}$ \\
\hdashline $\mathrm{TC}$ & 1 & & \\
\hline $\mathrm{EC}$ & 0.77 & 1 & \\
\hline $\mathrm{FS}$ & 0.89 & 0.67 & 1 \\
\hline \hline
\end{tabular}

(Tab. 5): Spearmen Correlation, between microbial indicators in sediments (during years 2012 -2013). 


\section{International Journal of Science and Research (IJSR) \\ ISSN (Online): 2319-7064}

Index Copernicus Value (2013): 6.14 | Impact Factor (2014): 5.611

\section{Results and Conclusions}

The distribution and seasonal variation of the Total Coliforms (TC), Fecal Coliforms (E. coli) and fecal streptococci (FS) in the water and sediments of Drini river and surface water of Kune Vain Lagoons, during the years 2012-2013 (table 1, graphic1).

In the water: By analytical assessment, the values of Total coliforms in water, ranging from $15 \mathrm{CFU} / 100 \mathrm{ml}$ (on January '12, point Vain 3) in $2.4 \times 10^{4} \mathrm{CFU} / 100 \mathrm{ml}$ (on March 13, in point 4 of Manatia - brook). Average values or lower total coliform were found in January and November '12 and January of '13 November, while average values higher are found in July '12, March and July '13. The Fecal coliform values with representatives of Escherichia coli in the water, ranging from $3 \mathrm{CFU} / 100 \mathrm{ml}$ (in July and November '13 at point Kune 1) in $18.9 \times 10^{3} \mathrm{CFU} / 100 \mathrm{ml}$ (on March 13, in point 4 - Manatia brook). Average values or lower of the Fecal coliform are found in the January and November '12, January and '13 November, while average values higher are found in July '12, March and July '13. Referring NIVA's classification, for the parameters of Coliform bacteria, in the relation to the environmental quality of water, it is observed that $3.3 \%$ of the samples belong to the class I (environmental quality and very good); $40 \%$ of the samples belong to the class II (good environmental quality); 19.2\% of water samples belong to the class III (average environmental quality); $16.7 \%$ of water samples belong to the class IV (bad environmental quality); $20.8 \%$ of water samples belong to the class $\mathrm{V}$ (very bad environmental quality). The highest percentage of water samples class II and III, are monitoring points taken in the waters of the Kune Vain Lagoons; water samples taken at the station points 1, 2, 3, 14 and 15 belong to class IV; water samples taken at the station points in the Drini River (point 1 - point 5) belong to class V. The values of Fecal Streptococci in water, ranging from $0 \mathrm{CFU} / 100 \mathrm{ml}$ (almost the entire period, except March '13) to $22.6 \times 10^{3}$ CFU/100 $\mathrm{ml}$ (on March 13, point 4 - Manatia brook). The average values or lower fecal streptococci are found in January '12, January '13 and November '13, while average values higher are found in March of 2012 - 2013.

Referring to the USEPA regulatory level (1986), in relation to the values of microbial indicators E. Coli (as a representative of Fecal coliform) and Enteroccocci (as a representatives of Fecal streptococci) for the indicator was observed that E. coli, to analyze the quality of waters in this study conform $70 \%$ of the samples, and $30 \%$ are not in conformity with $25 \%$ of the stations in the sampling on the Drini River by points $1-5$ and $5 \%$ belong to samples taken at the estuary of the Drini River in points D 14 and D 15). Water samples taken at sampling stations in two lagoons are all conform to the values determined by this regulation (235 CFU/100 $\mathrm{ml}$ for a single sample). For indicator Enteroccocci (with representatives Fecal streptococci), was observed that water samples analyzed in this study are conform $72 \%$ of the samples, and $28 \%$ are not conform with $(25 \%$ of water samples taken in the Drini River, points 1 to 5 and 3\% belong to samples taken at the estuary of the Drini River in points D 14 and D 15).
To receive information on the origin of pollution is using a ratio between fecal coliform (FC) and Fecal streptococci (FS) in samples of surface water and groundwater. If this ratio is 4 or greater, indicates human pollution source, the relationship between $0.1-0.6$ shows the source of pollution from household animals, if the ratio is less than 0.1 indicates that the source of contamination is from wild animals. Results of the present study show that there is an origin mixed of fecal contamination in the Drini River for rural and urban discharges, livestock and industrial flow into this river, although the points D1 - D5 are the highest observed value FC, since in these points discharges mainly urban waters untreated (Ceni Bridge, point 4 or Manatia brook, Industrial areas - point 5 and Torovica collector - point 3) but the ratio FC/FS says several months with lower than 4, as have some polluting sources. Pollution sanitation may be caused by point source pollution such as discharges of sewage from human resources or enterprise livestock and from non point pollution, such as pastures, run-off of agricultural land, the water flows as a result of floods (Kirschner et al., 2004).

In the sediments: By analytical assessment, the values of total coliforms in sediments, ranging from $3.3 \times 10^{4} \mathrm{CFU} /$ $100 \mathrm{ml}$ (point D 15) to $1.6 \times 10^{5} \mathrm{CFU} / 100 \mathrm{ml}$ (point 4 stream of Manatia), Fecal coliform values (E. Coli), ranging from $9.5 \times 10^{3} \mathrm{CFU} / 100 \mathrm{ml}$ (point 7 - Vain 2) to $1 \times 10^{5}$ CFU/100 ml (point 4 - Manatia brook) while Fecal streptococci values ranging from $1.2 \times 10^{2} \mathrm{CFU} / 100 \mathrm{ml}$ (point 14) to $1.9 \times 10^{4} \mathrm{CFU} / 100 \mathrm{ml}$ (point 1- Gocaj bridge). Average values or lower Total coliform, fecal coliform and Fecal streptococci were found in sediments in July '12 while average values higher are found in November '13 (graph. 2).

The Statistical Analysis: Data processing and statistical analysis, the variables variance for $\mathrm{p}=0.01$ ANOVA, or $\mathrm{p}=$ 0.05 was performed with SPSS ver.19. Through ANOVA, which was used to see whether or not the difference between the averages, which has resulted in a statistically significant difference between microbial indicators in water and sediment, so variables (indicators) are independent of each other. Variables are tested for normal distribution (test of Normality, Kolmogorov-Smirnova and Shapiro-Wilk) they proved that do not belong to the normal distribution for microbial indicators in water and sediments, (figure 3.4). Box plots, which represent graphically distribution of data (based on the summary of five numbers, minimum, the first quartile, median, the third quartile, and maximum). For visualization of data and market results of the microbiological water sediments are used charts below (Figure 5, 6).

Non-parametric test is used, Spearmen correlation, for $\mathrm{p} \leq$ 0.05 to evaluate the relationship between variables. The data tables show that we have a strong positive relation between microbial indicators in water (Tab. 4) and in sediments (Tab. $5)$, with growth of one variable increases and other variables. By analytical evaluation of samples for microbiological indicators is observed that in sediments samples the values of these indicators, have resulted in higher than in samples of water. The highest values of three microbiological indicators are found in the sampling points in the Drini River, followed by the water samples taken at the estuary of the Drini River. Values lower averages of Total coliform, Fecal coliform and fecal streptococci in water are found in autumn and winter, 


\section{International Journal of Science and Research (IJSR) \\ ISSN (Online): 2319-7064}

Index Copernicus Value (2013): 6.14 | Impact Factor (2014): 5.611

while the highest average values are found in the spring and summer. Lower values of averages of Total Coliform, Fecal Coliform and Fecal streptococci are found in the sediments in July '12, while average values higher are found in November '13.

\section{References}

[1] Kavka, G. G., Kasimir, D. \& Farnleitner, A. H. (2006). Microbiological water quality of the River Danube $(\mathrm{km}$ $2581-\mathrm{km} \mathrm{15)}$ : longitudinal variation of pollution as determined by standard parameters. In Proceedings of the 36th International Conference of the IAD, pp. 415421. International Association of Danube Research.

[2] A.J. Turki and MS. A. (2008) Mudarris. Bacteria and Nutrients as Pollution Indicators in the Al-Nawrus Recreational Lagoon, Jeddah. JKAU: Mar. Sci., Vol. 19, and pp: 77-93.

[3] Jamieson, R., Joy, D.M, Lee, H., Kostaschuk, R., and Gordon, R. (2005). Transport and deposition of sediment-associated. Escherichia coli in natural streams. Water Res. 39(12), 2665-2675.

[4] Ishii, S., Hansen D.L., Hicks, R.E., and Sadowsky, M.J. (2007). Beach sand and sediments are temporal sinks and sources of Escherichia coli in Lake Superior. Environ. Sci. Technol. 41(7), 2203-2209.

[5] Kirschner, A. K., Kavka, G. G., Velimirov, B., Mach, R. L., Sommer, R. \& Farnleitner, A. H. (2009). Microbiological water quality along the Danube River: integrating data from two whole-river surveys and a transnational monitoring network. Water Res 43, 3673 3684.

[6] http://www.water-research.net/index.php/bacteria-in-theenvironment-and-drinking-water.

[7] Irvine, K., G.W. Pettibone and I. Droppo. 1995. "Indicator Bacteria-Sediment Relationships: Implications for Water Quality Modeling and Monitoring." Journal of Water Management Modeling. ISSN: 2292-6062.

[8] Alexandria B. Boehm and Lauren M. Sassoubre. Enterococci as Indicators of Environmental Fecal Contamination; Enterococci /Editorial. February 24, 2014.

[9] L. W. Sinton, A. M. Donnison \& C. M. Hastie (1993) Faecal streptococci as faecal pollution indicators: Part I: Taxonomy and enumeration, New Zealand Journal of Marine and Freshwater Research, 27:1, 101-115, DOI: 10.1080/00288330.1993.9516549.

[10]EPA (1999) United States Environmental Protection Agency, 1999. Action plan for beaches and recreational waters. EPA 600-R-98/079. Washington, DC: EPA.

[11]EU (2006). Directive 2006/7/EC of the European Parliament and of the Council of 15 February 2006 concerning the management of bathing water quality. Official Journal of the European Union, 64, pp 37-51.

[12]An, Y. -J., Kampbell, D. H., \& Briedenbach, G. P. (2002). Escherichia coli and total coliforms in water and sediment at lake marinas. Environmental Pollution, 120(3), pp 771-778.

[13] Garcia-Armisen, T., \& Servais, P. (2007). Respective contributions of point and non point sources of $E$. coli and enterococci in a large urbanized watershed (the Seine River, France). Journal of Environmental Management, 82(4), pp 512-518.

[14]U.S. Environmental Protection Agency. (2004). Nonpoint source technical note \#73.

[15]Ferguson, C. M., Coote, B. G., Ashbolt, N. J., and Stevenson, I. M. (1996). Relationships between indicators, pathogens and water quality in an estuarine system. Water Research, 30, pp 2045-2054.

[16] WHO (2006). Guidelines for safe recreational water environments. VOLUME 2: SWIMMING POOLS AND SIMILAR ENVIRONMENTS.

[17] MMPAU (2010). Assessment of deficiencies of protected areas, marine biodiversity and legislation for marine protected areas.

[18] The final report. Preparation of management plan marshy area of Kune-Vain for the period 2010-2019.

[19]APHA (1998). Standard Methods for the Examination of Water and Waste Water, 20h ed. American Public Health Association, Washington, DC.

[20] WHO (1998). Draft Guidelines for Safe Recreational Water Environment: Coastal and Fresh Water, World Health Organization, Geneva.

[21]WHO (2002). The World Health Report 2002 Reducing Risks, Promoting Healthy Life. Geneva: World Health Organization.

[22] Environment Institute. Albania. Selection and development of methods of sampling and analysis of environmental pollutants in water monitoring.

\section{Author Profile}

Anilda Kokali. Received M.D in Engineering, Environmental Science, following is pursuing $\mathrm{PhD}$ studies at the Faculty of Agriculture \& Environment, Agricultural University of Tirana. 